\title{
Effects of nutrient enrichment and grazing on shoalgrass Halodule wrightii and its epiphytes: results of a field experiment
}

\author{
K. L. Heck Jr. ${ }^{1,2, *}$, J. F. Valentine ${ }^{1,2}$, J. R. Pennock ${ }^{3}$, G. Chaplin ${ }^{4}$, P. M. Spitzer ${ }^{1}$ \\ ${ }^{1}$ Dauphin Island Sea Lab, 101 Bienville Boulevard, Dauphin Island, Alabama 36528, USA \\ ${ }^{2}$ Department of Marine Science, University of South Alabama, Mobile, Alabama 36688, USA \\ ${ }^{3}$ Marine Program, University of New Hampshire, 56 College Road, Durham, New Hampshire 03824, USA \\ ${ }^{4}$ Auburn University Extension Service, 101 Bienville Boulevard, Dauphin Island, Alabama 36528, USA
}

\begin{abstract}
We assessed the individual and combined effects of removing large predators and enriching water column nutrients on shoalgrass Halodule wrightii meadows in Big Lagoon, Florida, USA. To simulate the first-order effects of large predator reductions, we stocked $2.0 \mathrm{~m}^{2}$ enclosures with elevated ( $\sim 3$ to $4 \times$ ambient) densities of the omnivorous pinfish Lagodon rhomboides, the dominant fish in local seagrass habitats, and we supplemented N and P in the water column to nearly $3 \times$ ambient levels. Monthly determinations of water column nutrients and chlorophyll a (chl a), coupled with bimonthly measurements of leaf epiphyte biomass, seagrass growth and biomass, and beginning and ending comparisons of mesograzer abundance, were used to evaluate the effects of increasing nutrient supply and changing food web structure. Results showed significant predator and nutrient effects, although there were fewer consumer effects and more negative nutrient effects on seagrasses than in our previous experiments, which had shown that mesograzers ameliorated the harmful effects of elevated nutrients on seagrasses. Epiphyte proliferation in enrichment treatments did not occur; thus, algal overgrowth could not explain the negative effects of nutrient loading on seagrass biomass. Instead, nutrient loading resulted in nitrogen-rich shoalgrass, and it appears that this high-quality food stimulated pinfish herbivory. Elevated pinfish consumption of the enriched shoalgrass then resulted in the decline of seagrass biomass in enrichment enclosures. These results add additional complexity to understanding and predicting the effects of eutrophication in coastal waters.
\end{abstract}

KEY WORDS: Seagrass $\cdot$ Nutrients $\cdot$ Herbivory $\cdot$ Trophic cascades $\cdot$ Pinfish

Resale or republication not permitted without written consent of the publisher

\section{INTRODUCTION}

Global human fixation of nitrogen has increased 2- to 3 -fold since 1960 and global riverine discharges of nitrogen have almost doubled over the past 2 centuries (NAS 2000). This increasing input of nutrients to the coastal ocean has been closely linked to many negative impacts on biological resources (NSF 2000), and a variety of recent summaries argue that eutrophication is the most serious of human impacts on nearshore waters (Howarth et al. 2000, NAS 2000, NSF 2000). The most obvious consequences of coastal eutrophication include increasing occurrences of hypoxic and anoxic events, and elevated frequencies and extents of harmful algal blooms (HABs), both of which are often associated with extensive fish kills and the overgrowth of extraordinarily productive seagrass meadows and coral reefs by rapidly growing macroalgae (Howarth et al. 2000).

Certain key characteristics appear to determine responses to coastal eutrophication. They include biotic factors such as the composition and relative abundance of the primary producers and consumers present, physical factors such as estuarine geomorphology, stratification, and nutrient loading rate, as well as hydrodynamic factors such as water residence time and flushing characteristics (NAS 2000). 
Among these factors, the types and abundances of herbivores present may be seriously underrated determinants of the severity of the effects of eutrophication in coastal systems (Duffy et al. 2003). Evidence supporting this hypothesis comes from a variety of locations and types of herbivores. For example, experimental studies of nutrient enrichment have indicated that small benthic herbivores such as amphipods and gastropods, which can consume their body weight or more in algae daily (for a review see Jernakoff et al. 1996), can offset the effects of nutrient enrichment on seagrass meadows (Neckles et al. 1993, Williams \& Ruckelshaus 1993, Heck et al. 2000). Very similar results have recently been reported for coral reefs, where the effects of experimental nutrient enrichment were negligible when herbivorous fishes were present (Larkum \& Koop 1997, Miller et al. 1999), and for aquatic microalgae growing on ceramic tile substrates, where the effects of nutrient addition on algal growth were balanced by amphipod and gastropod consumption (Lotze \& Worm 2002).

An increasing number of well-documented studies implicate fishing as both a direct and indirect cause of shifts in herbivore numbers and species compositions, often with dramatic effects on algal biomass (for a review see Steneck \& Carlton 2001). Two especially well-known cases discussed by Steneck \& Carlton (2001) involve sea urchin herbivores from cool temperate shores of both the east and west coasts of the United States. On the west coast, after their sea otter predators were overharvested, sea urchin populations increased dramatically, and the feeding activities of the larger urchin populations led to dramatic decreases in the size of kelp forests. On the east coast, significant reductions in the density of finfish predators also led to increased urchin abundance, causing similar largescale kelp disappearances. Recent intense harvesting of sea urchins for the export market during the 1990s has dramatically reduced their numbers, resulting in predicted large increases in kelp abundance.

Studies have also shown that herbivores in seagrass meadows (as well as in mangroves and on coral reefs; Boyer et al. 2004) can differentiate between nutrientenriched and unenriched plants and strongly prefer to feed on nutrient-enriched tissues. Williams (1987) was one of the first to document that nutrient enrichment of turtlegrass sediments led to consumption of virtually all leaf tissue by small parrotfish within 1 wk. Subsequently, McGlathery (1995) reported nearly total removal of aboveground turtlegrass biomass only $9 \mathrm{~d}$ after enrichment, and Goecker et al. (2005) found similar results for turtlegrass leaves from eutrophic waters. In their study, near total consumption of enriched leaves occurred and was 5 to 15 times greater than that of leaves from oligotrophic waters. These studies clearly show that seagrasses can accumulate nitrogen from the water column, and that herbivores will feed selectively on nitrogen-rich seagrass leaves. This could then result in reduced algal accumulation in nutrientenriched seagrass meadows as leaves are consistently cropped, thereby eliminating settlement sites for epiphytic algal spores.

Here we report the results of a test of the hypothesis that consumption by small herbivores can effectively buffer seagrasses from the negative effects of algal overgrowth in eutrophic waters. To do this we conducted field studies at small spatial scales that allowed us to easily manipulate consumer density and elevate nutrient concentrations to levels that mimic those of highly eutrophic coastal waters. Our focus is on seagrass-dominated ecosystems because they are wellknown as essential nursery habitats for a broad variety of economically valuable finfish and shellfish (for a review see Heck et al. 2003), and because, as noted above, eutrophication is strongly implicated in their disappearance (e.g. Howarth et al. 2000).

The species we manipulated, the pinfish Lagodon rhomboides, dominates the small fish fauna in northern Gulf of Mexico seagrass meadows from spring to fall (Huh 1984, Stoner \& Livingston 1984). Many investigators have recognized the ability of pinfish to control invertebrate and epiphyte abundance (Stoner \& Livingston 1984, Luczkovich \& Stellwag 1993, Heck et al. 2000). Stomach content analyses show that distinctive feeding stages exist, which vary depending on the area sampled and the time of year (Stoner \& Livingston 1984, Luczkovich \& Stellwag 1993). In both Florida and North Carolina pinfish are omnivorous when small (approximately 26 to $40 \mathrm{~mm}$ SL) and feed heavily on polychaetes, small crustaceans, and epiphytes. As they grow (from 40 to $120 \mathrm{~mm} \mathrm{SL}$ ) algae become increasingly more common in their diet. Finally (>120 mm SL), pinfish feed almost entirely on both algae and seagrasses (cf. Luczkovich \& Stellwag 1993).

Study site. Big Lagoon, Florida, located in the Perdido Bay system in the north central Gulf of Mexico $\left(30^{\circ} 23^{\prime} \mathrm{N}, 87^{\circ} 24^{\prime} \mathrm{W}\right)$, is a semi-enclosed lagoon characterized by low energy regimes. In the shallows $(<2 \mathrm{~m})$ it contains seagrass meadows dominated by turtlegrass Thalassia testudinum and shoalgrass Halodule wrightii, along with unvegetated sand flats. Salinity generally ranges from mesohaline to polyhaline (13 to 30 psu annually; Spitzer et al. 2000), temperature varies seasonally from approximately 7 to $30^{\circ} \mathrm{C}$ (authors' pers. obs.) and the mean tidal range is $0.5 \mathrm{~m}$ (Spitzer et al. 2000). Our previously unpublished measurements have shown relatively low summer nutrient levels, ranging from 0.01 to $2.73 \mu \mathrm{M}$ nitrate, 0.3 to $2.6 \mu \mathrm{M}$ ammonium, 0.0 to $15.35 \mu \mathrm{M}$ silicate and 0.0 to $0.14 \mu \mathrm{M}$ phosphate. We have also observed that sum- 
mer water column chl a values are low, ranging from 0.17 to $6.16 \mu \mathrm{g}^{-1}$ (unpubl. data).

\section{MATERIALS AND METHODS}

Experimental design. To test the combined effects of nutrient enrichment and increased pinfish density on mesograzer abundance and species composition, epiphyte abundance, and seagrass biomass and growth, 24 approx. $2 \mathrm{~m}^{2}(1.4 \times 1.4 \mathrm{~m})$ enclosures were installed in a dense stand of shoalgrass, parallel to shore at depths of approx. $1 \mathrm{~m}$. Each enclosure was made of plastic net $(1.2 \times 1.6 \mathrm{~cm}$ mesh $)$ held in place by a PVC frame. Bird netting tops ( $1.9 \mathrm{~cm}$ mesh) maximized light passage and prevented fish from entering or leaving enclosures.

The experiment's two main effects, pinfish density manipulation (ambient density pinfish $=1 \times \mathrm{F}$, and elevated pinfish density $=10 \times \mathrm{F}$ ) and nutrient enrichment (ambient $=-\mathrm{N}$ and elevated nutrient concentrations $=$ $+\mathrm{N})$, were tested in a factorial design. Each treatment had 6 replicates and treatments were randomly assigned. Cross-contamination was avoided by increasing the spacing between the nutrient and nonnutrient cages. To establish baseline conditions, preexperiment sampling (Time 0, T0) was conducted on May 22, 2000, and all treatments were in place by the end of May 2000. The experiment was run for $139 \mathrm{~d}$ with midterm sampling (T1) of selected parameters in July and the final sampling (T2) during the second week of October 2000.

Nutrient additions. In each nutrient enclosure, PVC tubes $(11 \mathrm{~cm}$ diameter $\times 30 \mathrm{~cm}$ length with twenty $2 \mathrm{~cm}$ holes) containing $500 \mathrm{~g}$ dry wt (DW) of Osmocote ${ }^{\mathrm{TM}}$ slow release fertilizer $(\mathrm{N}: \mathrm{P}$ molar ratio $=16: 3)$ were attached to each cage leg at a distance of $10 \mathrm{~cm}$ above the substrate. One additional tube was suspended in the center of the cage within the seagrass canopy. Nutrients were replaced at approximately $4 \mathrm{wk}$ intervals, as previous studies (see below) have shown that the nutrients are initially released in a 'burst' with subsequent slow release over a number of weeks. Replacing the Osmocote ${ }^{\mathrm{TM}}$ every $4 \mathrm{wk}$ should have limited the amount of time between 'bursts' and resulted in high overall nutrient loading. The exteriors of nutrient tubes were cleaned with wire brushes where required, and hosed down during each replacement of Osmocote $^{\mathrm{TM}}$.

To characterize the dissolution rates of Osmocote ${ }^{\mathrm{TM}}$, laboratory experiments (reported in Heck et al. 2000) were conducted at temperatures commonly encountered during the seagrass growing season $(15,2025$, and $30^{\circ} \mathrm{C}$ ). Individual PVC tubes containing $500 \mathrm{~g} \mathrm{DW}$ of Osmocote ${ }^{\mathrm{TM}}$ were submerged in 30 psu seawater in
191 buckets that were mixed with magnetic stirrers. Five replicates were used for each temperature treatment. Samples were collected on Days 0 and 1, and subsequently at approximately $3 \mathrm{~d}$ intervals over a 10 to $15 \mathrm{~d}$ period. These experiments showed that fertilizer release occurred in an initial burst phase followed by a constant release rate until the nutrients were exhausted (cf. Fig. 2 in Heck et al. 2000). These laboratory data allowed us to estimate nutrient loading rates during our field experiments. During each nutrient tube replacement, 25 tubes (20 attached to support poles and 5 free hanging tubes) were collected and dried to a constant weight. Osmocote ${ }^{\mathrm{TM}}$ loss rates ( $g$ tube ${ }^{-1} \mathrm{~d}^{-1}$ ) were calculated based on the change in Osmocote $^{\mathrm{TM}}$ weight over time and $\mathrm{N}$ and $\mathrm{P}$ delivery rates $\left(\mathrm{mmol}\right.$ tube $\left.{ }^{-1} \mathrm{~d}^{-1}\right)$, and loading rates $\left(\mathrm{mmol} \mathrm{\textrm {m } ^ { - 2 }}\right.$ $\mathrm{d}^{-1}$ ) were calculated (Fig. 1; Table 2).

Fish manipulations. Previous studies have shown that such enclosures effectively excluded large fish predators (e.g. sharks, red drum, spotted sea trout, and jacks) while allowing smaller invertebrates (e.g. grass, shrimp) and fish smaller than the cage mesh (e.g. young-of-the-year pinfish) access and egress (cf. Heck et al. 2000).

Young-of-the-year pinfish Lagodon rhomboides were captured by trawling and used to stock $1 \times \mathrm{F}$ and $10 \times \mathrm{F}$ cages at densities of 6 ind. cage $^{-1}\left(\right.$ or $\left.3 \mathrm{~m}^{-2}\right)$ and 60 ind. cage $^{-1}$ (or $30 \mathrm{~m}^{-2}$ ), respectively. The majority of fish ranged in size from 73 to $100 \mathrm{~mm}$ in total length (TL), as pinfish $>73 \mathrm{~mm}$ TL could be retained by the mesh of the enclosures. Prior to pinfish additions, all cages were seined to remove fish larger than the cage mesh.

Our small predator treatments were initially estimated to approximate ambient pinfish densities (3 fish $\mathrm{m}^{-2}$ ) and 10× ambient 'natural' densities (30 fish $\mathrm{m}^{-2}$ )

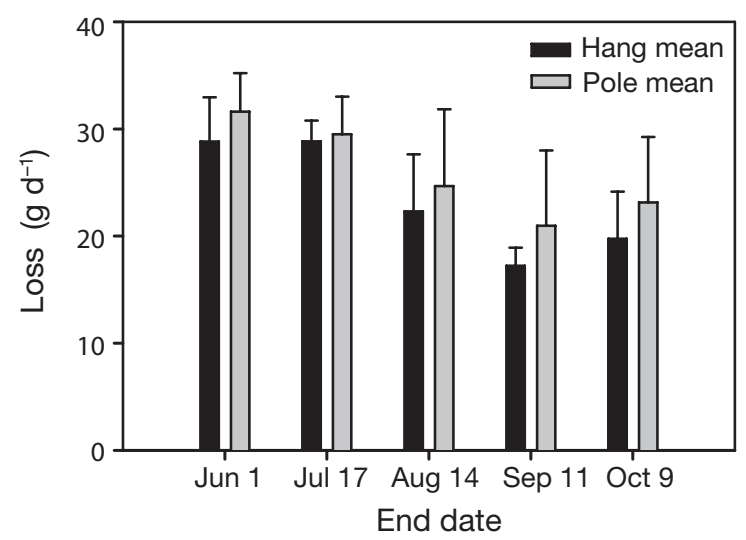

Fig. 1. Dissolution rates of Osmocote ${ }^{\mathrm{TM}}$ held in $5 \mathrm{~cm}$ diameter PVC tubes containing $500 \mathrm{~g}$ DW premeasured Osmocote ${ }^{\mathrm{TM}}$. Tubes were either hung on rebar stakes (noted as hang mean) or attached to the poles supporting the field enclosures (pole mean) 
in May. This ambient estimate was based on the few semi-quantitative studies of pinfish densities found in the literature. For example, mean pinfish density in Redfish Bay was estimated to be $2.3 \mathrm{~m}^{-2}$ (Huh 1984), and in St. Joseph Bay, Florida, density ranged from around 0.14 to $4.6 \mathrm{~m}^{-2}$ during the spring to fall months (Thompson 2000). However, because sampling of juvenile fish abundance using seines and trawls typically underestimates fish density by 30 to $70 \%$ (Kjelson \& Johnson 1978), we concluded that our initial stocking density was probably substantially lower than the nominal 10x 'natural' pinfish densities. For example, if our estimate of 3 fish $\mathrm{m}^{-2}$ were only $30 \%$ of actual densities, the actual abundances would be around $10 \mathrm{~m}^{-2}$. If they represented $70 \%$, actual densities would be around $4.3 \mathrm{~m}^{-2}$. Therefore, we estimate that our nominal $10 \times$ densities actually ranged from around 1.9 to $4.4 \times$ 'natural densities.' These 'enhanced' pinfish densities were used to simulate what might happen if large piscivorous predators were removed from the system by overharvesting, and pinfish populations responded by increasing their densities.

Sampling regime. All experimental plots were sampled monthly for water column nutrients and chl a concentrations from May to October in 2000, the period of greatest seagrass growth in the northern Gulf of Mexico (Valentine \& Heck 1991). During each nutrient sampling, duplicate water samples were collected from each enclosure to document the magnitude of our nutrient enrichment and its impact on water-column chl a concentrations. To minimize disturbance within the enclosures, water samples were collected at the canopy height from outside each enclosure. To do this, a $2 \mathrm{~m}$ long aluminum pipe containing Tygon tubing was inserted through the cage mesh and samples were collected using acid-washed $60 \mathrm{ml}$ syringes. Water samples were placed on ice until $(<2 \mathrm{~h})$ they could be filtered through Whatman ${ }^{\mathrm{TM}} \mathrm{GF} / \mathrm{C}$ filters and frozen in $60 \mathrm{ml}$ plastic bottles. Nutrient analyses were carried out on samples using standard wet chemical techniques (Skalar Manual Publication \# 0101022 A.US) adapted for use on an SANplus Autoanalyzer. Chl a concentrations were determined using a Turner Designs Model TD-700 Fluorometer following the acidification method of Lorenzen (detailed in Strickland \& Parsons 1972).

Bimonthly estimates of epiphyte chl a concentration and seagrass biomass were determined from shoots collected in 1 haphazardly placed $0.06 \mathrm{~m}^{2}$ core per enclosure. Samples were placed in prelabeled plastic bags, frozen and stored for later analyses. In the lab, 5 to 10 randomly selected shoots from each sample were used to measure leaf length and width (not reported separately here) and to quantify epibiota on the leaves.
All measured leaves were then scraped to remove epibionts, and the epibionts were then filtered onto a Whatman ${ }^{\mathrm{TM}} \mathrm{GF} / \mathrm{F}$ filter for chl $a$ analysis. We used this chlorophyll measure as a surrogate for the biomass of epiphytic algae.

Shoalgrass growth was estimated at the midpoint and end of the experiment using a modified clipping technique. One $10 \mathrm{~cm}$ diameter ring was placed in each cage and all plant material above the sheath was removed by cutting with scissors. Samples were collected within 10 to $14 \mathrm{~d}$ after clipping by inserting a corer into the ring and removing all above and below ground material. Any aboveground material within the core was considered new growth and was separated from the sample. All new leaves were dried to a constant weight at $80^{\circ} \mathrm{C}$ and ashed at $500^{\circ} \mathrm{C}$ for $3 \mathrm{~h}$ to estimate net aboveground primary production ( $g$ ashfree dry wt [AFDW] $\mathrm{m}^{-2} \mathrm{~d}^{-1}$ ). This method measures regrowth of seagrass leaves and is known to underestimate net above ground primary production by 38 to $56 \%$ (Hauxwell et al. 2001).

Invertebrate mesograzers were collected at the beginning and end of the experiment from each enclosure using a $0.07 \mathrm{~m}^{2}$ plastic cylinder whose lower edge was embedded in the sediment. The contents of the cylinder were sampled by a gasoline-powered suction pump (cf. Orth \& Van Montfrans 1987) and all material was passed through a $0.5 \mathrm{~mm}$ collecting bag where larger motile epibiota were retained. Following collection, samples were sieved on a $0.5 \mathrm{~mm}$ mesh screen to remove additional material, placed on ice, and frozen. Animals were identified only to the extent necessary to classify them trophically (Table 1), according to published information (cf. Neckles et al. 1993, Williams \& Ruckelshaus 1993). Free-living amphipods, caridean shrimp, and gastropods constituted the majority of mesograzers we collected.

Seagrass samples were taken at the beginning and the end of the experiment and used to determine $\mathrm{C}: \mathrm{N}: \mathrm{P}$ ratios of the leaves as a means of documenting the effectiveness of delivery of nutrients by the Osmo-

Table 1. Mesograzer categories used in classification of mobile epibiota

$\begin{array}{cc}\text { Gastropoda } & \text { Chitons } \\ \text { Turbo } & \text { Isopods } \\ \text { Rissoina } & \text { Amphipods } \\ \text { Modulus } & \text { Penaeid shrimp } \\ \text { Bittiolum } & \text { Caridean shrimp (minus alpheids) } \\ \text { Cerithium } & \text { Hermit crabs } \\ \text { Crepidula } & \text { Spider crabs } \\ \text { Mitrella } & \\ \text { Anachis } & \\ \text { Dentimargo } & \\ \end{array}$




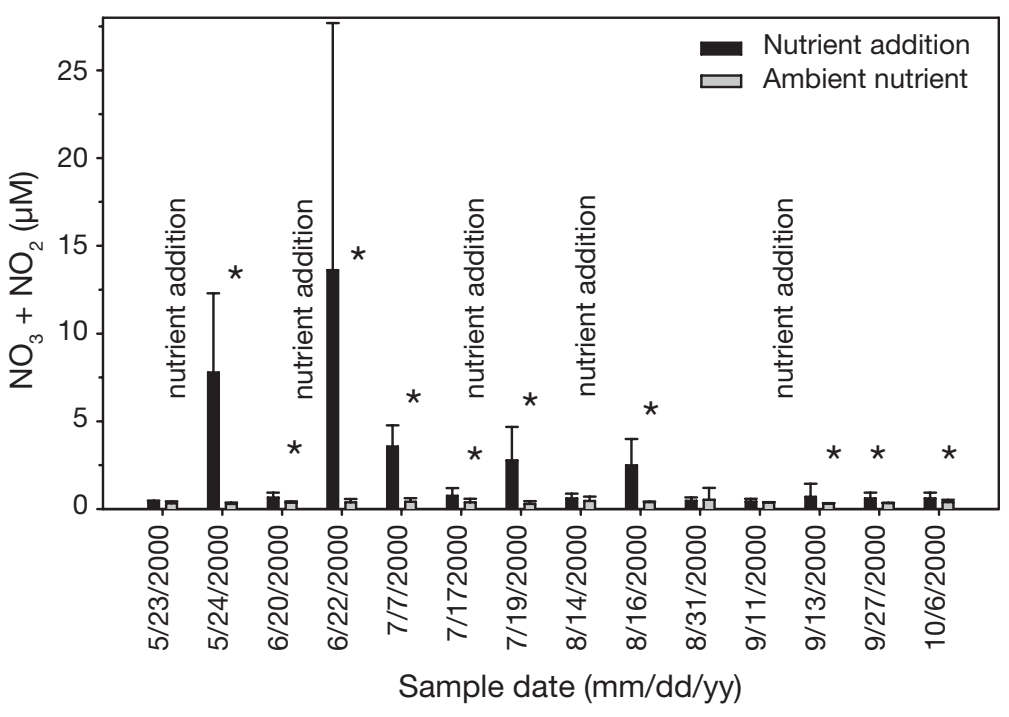

Fig. 2. Pooled nitrate and nitrite concentrations (+1 SE) by date during 2000. Nutrient additions are indicated, and significant differences in water column concentrations following nutrient additions are noted by an asterisk

\section{RESULTS}

\section{Water column nutrients and chl a}

Water samples collected in May before the start of the experiment were not significantly different in nitrate-nitrite, ammonium, or phosphate levels among treatments. While nutrient concentrations varied during the experiment as a result of natural input and wind-mixing, very large amounts of Osmocote ${ }^{\mathrm{TM}}$ were dissolved in the $+\mathrm{N}$ treatments, and nitrogen concentrations were often $3 \times$ greater than those in the $-\mathrm{N}$ plots (Figs. $2 \& 3$ ). Nitrogen levels decreased over time, but generally remained elevated in the $+\mathrm{N}$ treatments throughout the experiment (Figs. 2 \& 3), and high concentrations were consistently observed following the replacement of fertilizer tubes (Figs. 2 \& $3)$. Across all months, nitrite-nitrate con-

cote $^{\mathrm{TM}}$ in the enrichment treatments. An additional core was taken from each cage and haphazardly selected leaves were then removed from the sample and scraped of epibionts. The seagrass portion was dried at $60^{\circ} \mathrm{C}$ to a constant weight and then ground to a powder with a mortar and pestle. The dried samples were then analyzed for percent carbon and percent nitrogen in the Carlo Erba NA1500 CNS analyzer following a standard protocol (Carlo-Erba NA 1500 operating manual). Percent particulate organic phosphorus was determined using a standard wet chemical technique (Solorzano \& Sharp 1980).

Cage inspection and repair was conducted biweekly to ensure enclosure integrity. After the final sampling in October, all fish in each cage were collected by seining and were identified, enumerated and measured for TL and SL in mm.

Statistical analyses. Two-way analysis of variance (ANOVA) was used to analyze the effects of small predator manipulation and nutrient enrichment on measurements of seagrass biomass and growth, mesograzer abundance, epibiont abundance as estimated by chl $a$, inorganic nutrients, and water column chl a. Final fish counts were also analyzed using 2-way ANOVA. When data failed the homogeneity of variance assumption of ANOVA (according to Levene's test), data were log-transformed and retested to ensure that this assumption was met. Results were considered to be significant when $\mathrm{p}<0.05$, unless otherwise noted.

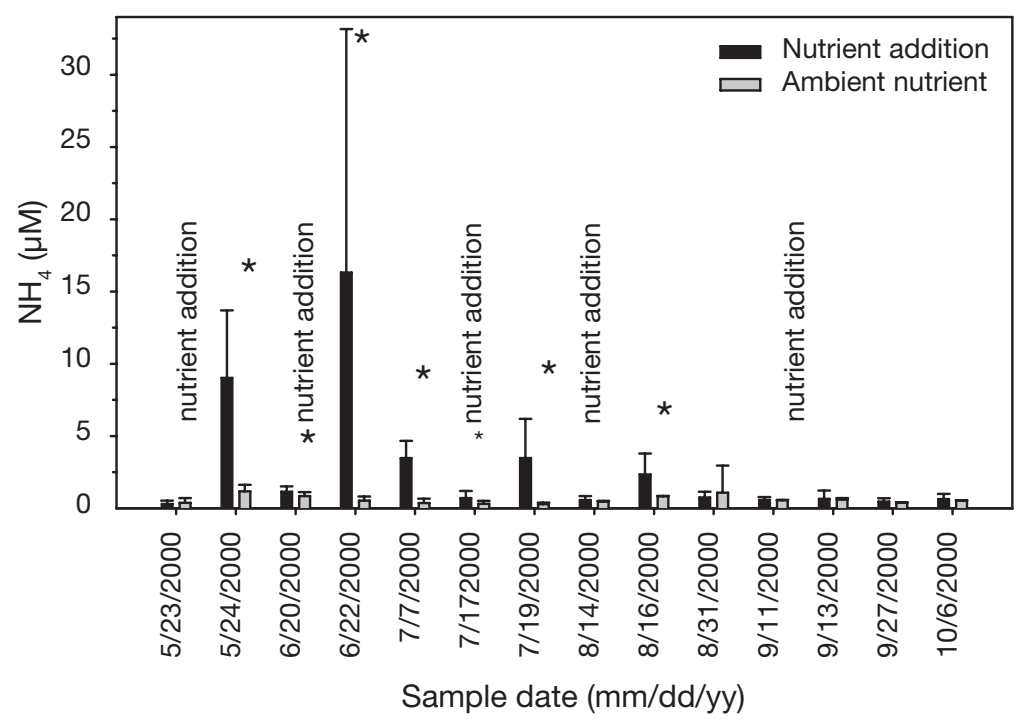

Fig. 3. Ammonium concentrations (+1 SE) by date during 2000. Nutrient additions are indicated, and significant differences in water column concentrations following nutrient additions are noted by an asterisk 


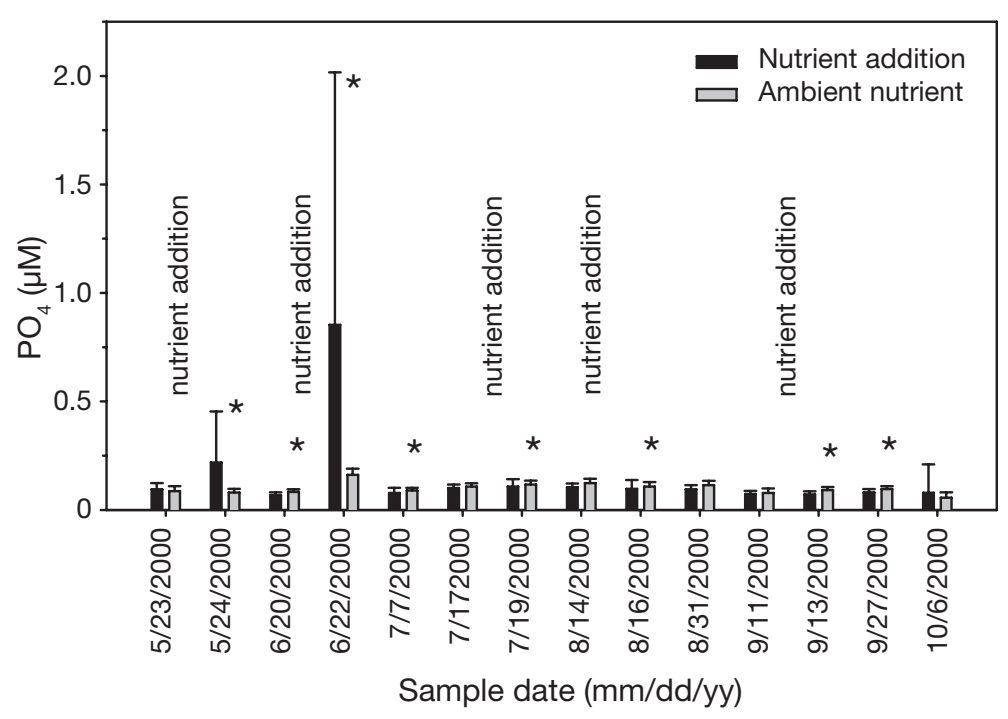

Fig. 4. Phosphate concentrations (+1 SE) by date during 2000. Nutrient additions are indicated, and significant differences in water column concentrations following nutrient additions are noted by an asterisk

ning of the experiment owing to natural spatial variability (Fig. 6). By the end of the experiment, although mesograzer densities declined by more than $50 \%$ within each treatment during the experiment (Fig. 6), there were no significant treatment effects ( $p>0.05)$. Unexpectedly, however, there were more, not fewer, mesograzers in the elevated pinfish treatments at the end of the experiment. However, this was primarily due to an abundance of the small gastropod Bittiolum varium, which is infrequently fed upon by juvenile pinfish (Luczkovich \& Stellwag 1993). When B. varium was removed from consideration and only crustacean mesograzers were analyzed, there were fewer grazers in the high density fish treatment, as expected, although differences were again not significant (Fig. 7).

\section{Epiphytes}

in June. Significant enrichment effects occurred during May, June, July, and the second sampling date in August (Fig. 3), but no significant effects were detected later in the year.

Phosphate concentrations ranged from $0.046 \mu \mathrm{M}$ (October) to $0.18 \mu \mathrm{M}$ (June) in the $-\mathrm{N}$ treatments (Fig. 4), and were highest in the $+\mathrm{N}$ treatments in June (nearly $1.0 \mu \mathrm{M})$ and lowest in September $(0.062 \mu \mathrm{M})$. Only twice was there a clear signal of elevated phosphate concentration (Fig. 4).

Even though water column concentrations were seldom measured at extremely high levels, nutrient loading rates were very high when compared to loading rates measured in prior studies (Table 2). Only the study by Harlin \& Thorne-Miller (1982) delivered nutrients at higher rates than we did, with loading rates in their experiment of approximately $10 \times$ that of our earlier experiments in turtlegrass meadows in St. Joseph Bay, Florida.

Water column chl a concentrations were variable (from 2 to nearly $8 \mu \mathrm{g} \mathrm{l}^{-1}$ ) and showed few treatment effects except in July and the final sampling in October (Fig. 5).

\section{Mesograzers}

There was substantial, albeit nonsignificant, heterogeneity in mesograzer abundance among treatment plots at the begin-
There were no significant differences in epiphyte chl a concentrations among treatments at the start of the experiment, although there was a significant fish effect on epiphyte chl $a$ at the midpoint of the experiment (Fig. 8; T1, $F_{1,28}=5.36 ; \mathrm{p}<0.03$ ), with less chl $a$ in high fish density treatments. By the end of the experiment, there were both significant nutrient and fish effects (Fig. $8 ; F_{1,28}=6.4, \mathrm{p}<0.02$ ), with significantly more chl $a$ on the seagrass leaves in the high nutrient

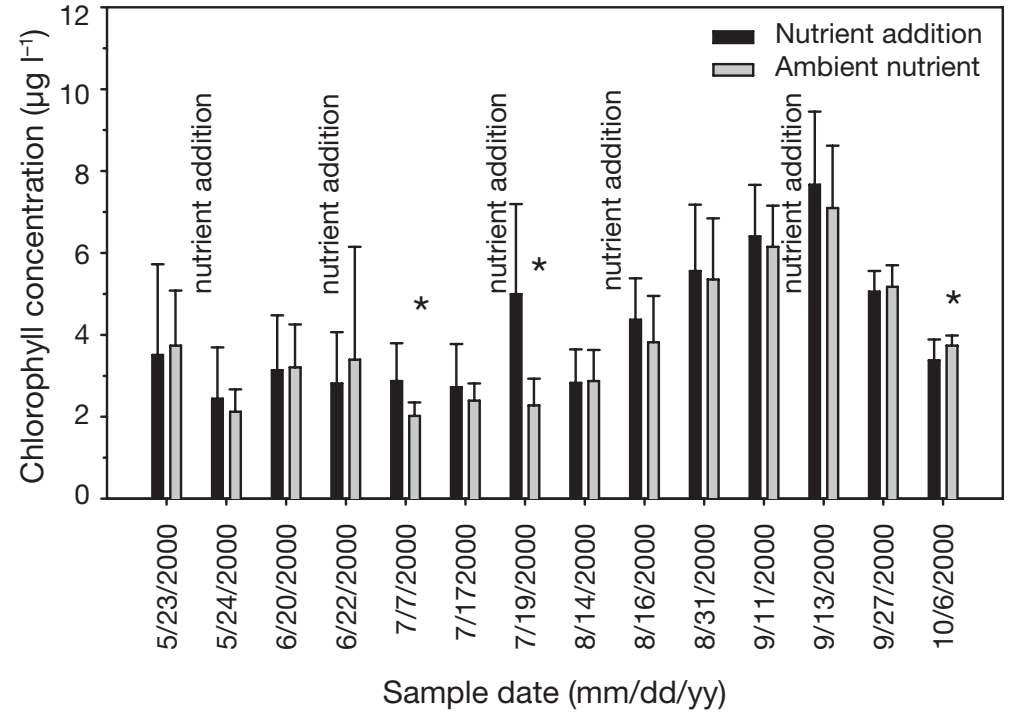

Fig. 5. Chl a concentrations (+1 SE) by date and treatment during 2000. Nutrient additions are indicated, and significant differences in water column concentrations following nutrient additions are noted by an asterisk 
Table 2. Estimated loading rates and measured nitrogen and phosphorus concentrations in the present study compared with those of previous experimental manipulations in seagrass systems and selected estuaries

\begin{tabular}{|c|c|c|c|c|c|c|}
\hline & $\begin{array}{c}\text { N-loading } \\
\left(\mathrm{mmol} \mathrm{m}^{-2} \mathrm{~d}^{-1}\right)\end{array}$ & $\begin{array}{c}\text { P-loading } \\
\left(\mathrm{mmol} \mathrm{m}^{-2} \mathrm{~d}^{-1}\right)\end{array}$ & $\begin{array}{l}\text { Ambient } \\
{[N](\mu \mathrm{M})}\end{array}$ & $\begin{array}{l}\text { Treatment } \\
{[\mathrm{N}](\mu \mathrm{M})}\end{array}$ & $\begin{array}{l}\text { Ambient } \\
{[\mathrm{P}](\mu \mathrm{M})}\end{array}$ & $\begin{array}{l}\text { Treatment } \\
{[\mathrm{P}](\mu \mathrm{M})}\end{array}$ \\
\hline \multicolumn{7}{|l|}{ Field manipulations } \\
\hline Present study ${ }^{a}$ & $576-886$ & $35-54$ & $0.3-0.5$ & $0.4-13.6$ & $0.06-0.2$ & $0.07-0.85$ \\
\hline Heck et al. $(2000)^{a}$ & $77-123$ & $5-7$ & $0.3-5.3$ & $0.5-7.0$ & $0.0-0.14$ & $0.1-0.4$ \\
\hline Harlin \& Thorne-Miller (1982) ${ }^{\mathrm{a}}$ & $1971-3857$ & $257-429$ & $0.4-2.3$ & $1.0-21.6$ & $0.0-1.0$ & $0.1-5.6$ \\
\hline Neckles et al. $(1993)^{b}$ & & & $4.0-10.8$ & $10.6-37.8$ & $10.7-1.6$ & $1.8-3.4$ \\
\hline Williams \& Ruckelshaus (1993) ${ }^{\mathrm{b}}$ & $476-510$ & & $3.6-45.0$ & $3.6-45.0$ & & \\
\hline McGlathery (1995) & 300 & 34.5 & $1.0-2.0$ & $4.0-4.5$ & $<0.05$ & 0.10 \\
\hline \multicolumn{7}{|l|}{ Selected estuaries ${ }^{c}$} \\
\hline Apalachicola Bay & & & 5.4 & & 0.2 & \\
\hline Chesapeake Bay & 1.9 & 0.11 & 20 & & 0.5 & \\
\hline Delaware Bay & 19.2 & 1.6 & 110 & & 1.2 & \\
\hline Narragansett Bay & 2.7 & 0.22 & 8.1 & & 1.9 & \\
\hline Thames Estuary, UK & 87.7 & 8.7 & & & & \\
\hline
\end{tabular}

treatments and in the ambient density fish treatments. However, mean epiphyte chl a concentrations were lower at the end than at the beginning of the experiment in all treatments except the nutrient enrichmentambient fish density treatment.

\section{Seagrass biomass and growth}

Seagrass biomass was significantly lower in the nutrient enrichment enclosures at the start of the experiment in May (T0) due to existing spatial heterogeneity and remained lower (although not significantly so) at the midpoint of the experiment in July (T1). At the end of the experiment in October (T2), biomasses were once again significantly lower in the nutrient enrichment treatments (Fig. 9; $F_{1,28}=12.36$; $\mathrm{p}<0.01$ ). No significant fish effects were observed at the end of the experiment. Even though the biomass in the elevated nutrient treatment was significantly lower than the ambient treatment at T0, all treatments decreased in biomass by the end of the experiment. The observed decreases were proportionally greater in nutrient than in fish treatments; thus, there was greater seagrass biomass decline in the nutrient addition enclosures.

Although no seagrass growth measurements were made in individual enclosures at the beginning of the experiment (to minimize disturbance), at the midpoint there were no significant differences among treatments. By the end of the experiment in October, however, there were significant nutrient effects (Fig. 10; $\left.F_{1,28}=7.02 ; \mathrm{p}<0.02\right)$ : seagrass in treatments with added nutrients grew significantly slower than treatments with ambient nutrient concentrations.

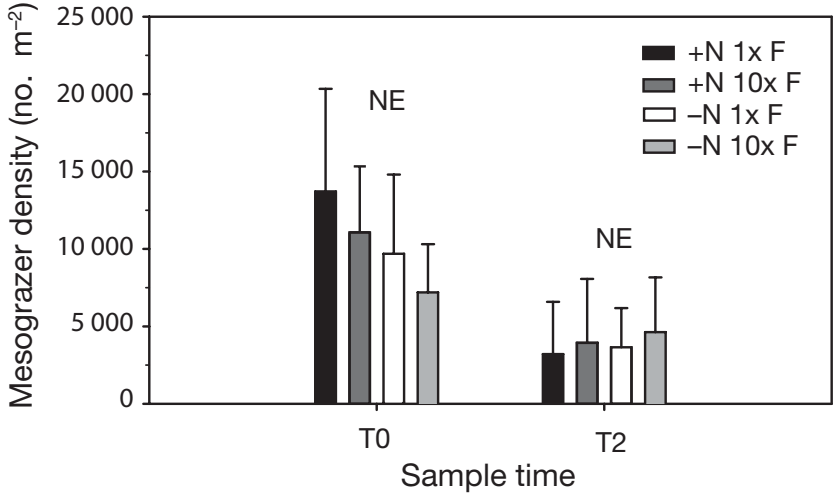

Fig. 6. Grazer density by sample time (T0, T2) and treatment during 2000. Treatments represented by: $-\mathrm{N}=$ no nutrient additions $;+\mathrm{N}=$ nutrient additions; $1 \times \mathrm{F}=$ ambient pinfish; and $10 \times \mathrm{F}=$ pinfish additions. NE $=$ no significant effects. Error bars $+1 \mathrm{SE}$

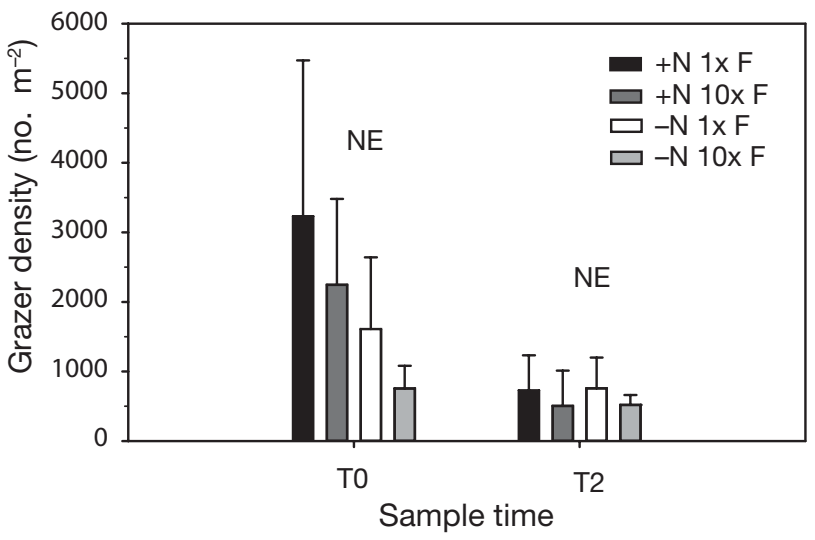

Fig. 7. Grazer density without Bittiolum varium (no. $\mathrm{m}^{-2}$ ) by month and treatment during 2000. Abbreviations as in Fig. 6. Error bars $+1 \mathrm{SE}$ 


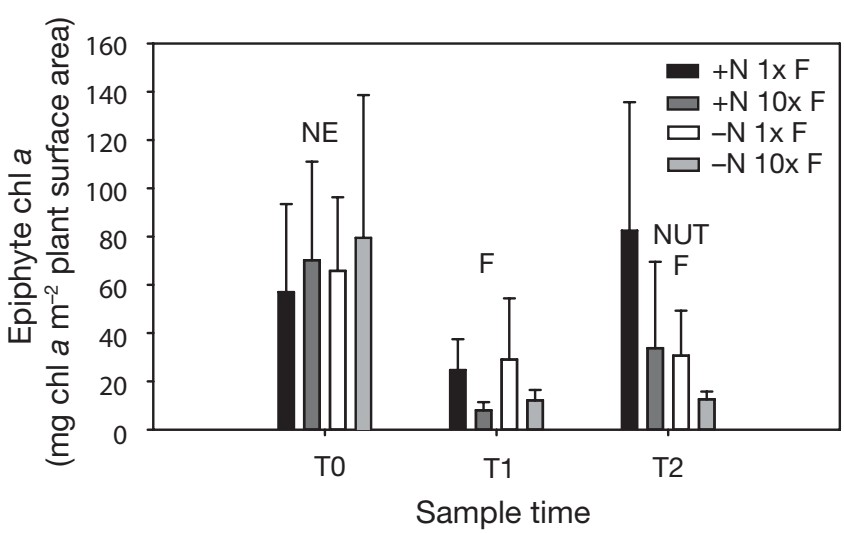

Fig. 8. Epiphyte chl a by month and treatment during 2000. NE: no significant effects; F: significant pinfish effects; NUT: significant nutrient effects. Abbreviations as in Fig. 6. Error bars + $1 \mathrm{SE}$

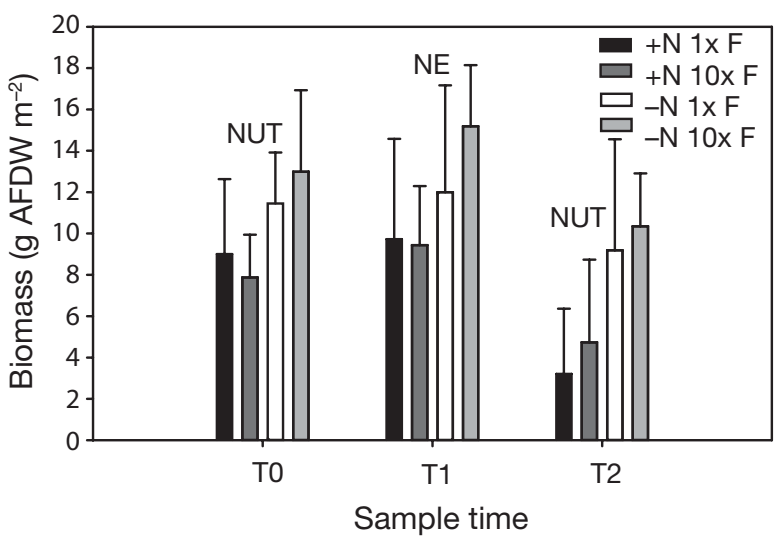

Fig. 9. Aboveground plant biomass by month and treatment during 2000. AFDW: ash-free dry wt. Other abbreviations as in Figs. 6 \& 8. Error bars $+1 \mathrm{SE}$

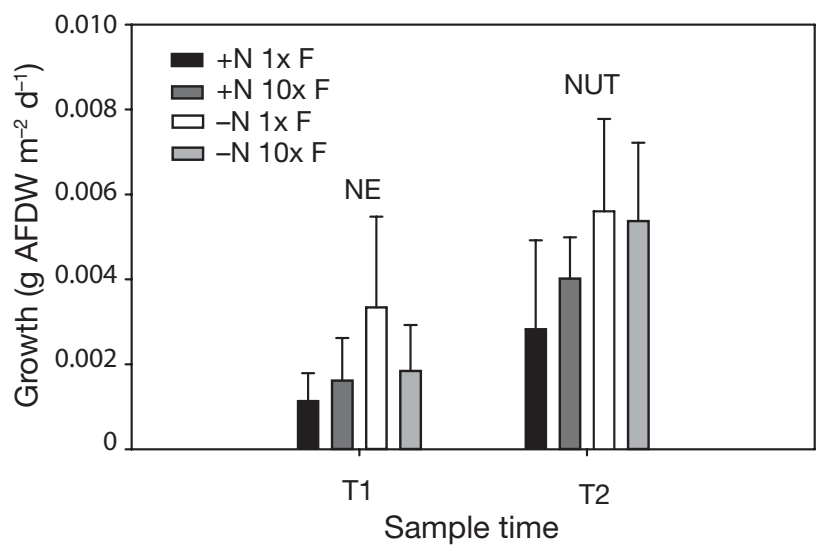

Fig. 10. Mean leaf growth by sample time and treatment. Abbreviations as in Figs. 6 \& 8. Error bars $+1 \mathrm{SE}$

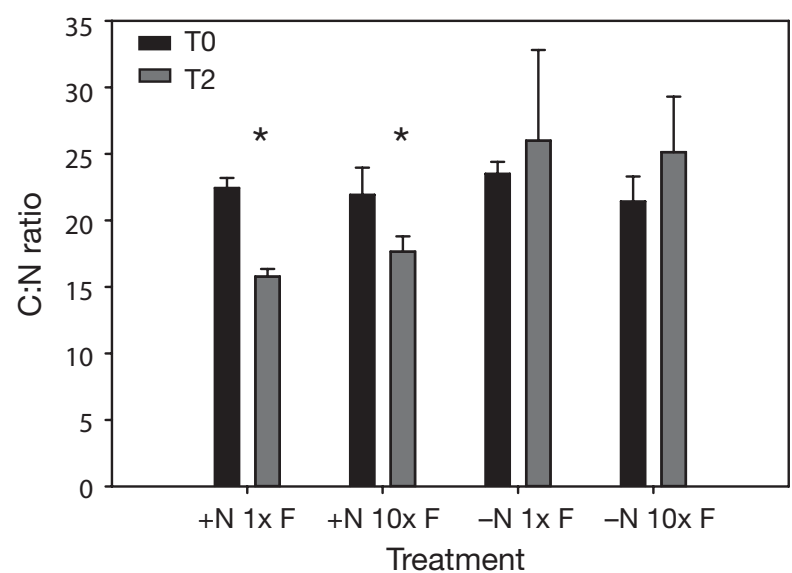

Fig. 11. C:N ratios by sample time $(\mathrm{T} 0, \mathrm{~T} 2)$ and treatment during 2000. Abbreviations as in Fig. 6. Error bars +1 SE. *Significant differences $(\mathrm{p}<0.01)$

\section{Effectiveness and maintenance of treatments during the experiment}

At the time of the final sampling in October, additional seagrass leaves were collected to compare C:N and C:P ratios between nutrient treatments. Results clearly indicated that leaf $\mathrm{C}: \mathrm{N}$ ratios were significantly reduced in nutrient addition enclosures (Fig. 11). Although there were no significant reductions in C:P ratios, all treatments did show reductions in C:P ratios by the end of the experiment (Fig. 12). In addition, it is noteworthy that results for the $-\mathrm{N}$ treatments show no evidence that the presence of fish or their excretory products were taken up by the seagrass leaves.

Initially, Lagodon rhomboides was stocked at $6(1 \times \mathrm{F}$ treatments) and 60 fish per cage $(10 \times \mathrm{F}$ treatments). Six mo later pinfish numbers had declined in all enclosures (presumably because of escapes or mortality), so that the $10 \times \mathrm{F}$ treatments contained approximately 7 to $8 \times$ the density of ambient density enclosures (Fig. 13). Nevertheless, this difference was highly significant $\left(F_{1,34}=186.95 ; \mathrm{p}<0.0001\right)$. Additional immigrant fish species removed from cages included small pigfish, toadfish, pipefish, and gobies. These additional species never exceeded a mean density of $>0.2$ fish cage $^{-1}$. Pinfish in the enclosures ranged from 50 to $135 \mathrm{~mm}$ TL, with the majority in the 70 to $100 \mathrm{~mm}$ TL range (Fig. 14). Only about 10 to $15 \%$ of these fish were smaller than the size $(<72 \mathrm{~mm} \mathrm{SL})$ that was able to enter the enclosures, and they therefore represent fish that colonized the enclosures during the experiment. In addition, nearly $10 \%$ of the fish in the enclosures grew to sizes greater than $100 \mathrm{~mm} \mathrm{SL}$, and these fish were of the size that frequently consumes seagrass leaves (Luczkovich \& Stellwag 1993). 


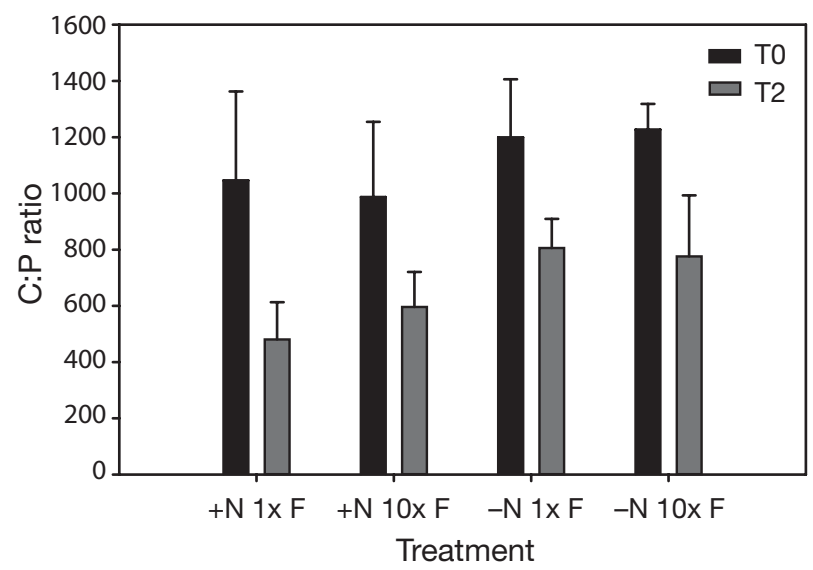

Fig. 12. C:P ratios by sample time $(\mathrm{T} 0, \mathrm{~T} 2)$ and treatment during 2000. Abbreviations as in Fig. 6. Error bars $+1 \mathrm{SE}$

\section{DISCUSSION}

The conventional wisdom regarding the effects of nutrient enrichment on submerged aquatic vegetation (SAV) has been that increasing nutrient supplies lead to the overgrowth of seagrasses by fast-growing algae, resulting in the eventual disappearance of seagrasses from eutrophic systems (Duarte 1995, Howarth et al. 2000, NAS 2000, Hauxwell et al. 2001). This is the explanation most often proposed to account for the loss of seagrasses in North America (Short et al. 1995), Europe (Giesen et al. 1990), and Australia (Cambridge \& McComb 1984). However, as noted previously (Heck et al. 2000), experimental studies that included manipulations of mesograzers (small crustacean, gastropod, or fish grazers) in their design have consistently found that grazing effects on epiphytic algal biomass were more significant than those of nutrient enrichment. In our previous experiments in turtlegrass meadows (Heck et al. 2000) we, too, found few significant nutrient effects. In contrast, manipulation of pinfish densities resulted in significant effects on mesograzer density, epiphyte biomass, and the production, leaf length, and shoot density of Thalassia testudinum. In aggregate, the results from these studies, many of which have been reviewed previously by Jernakoff et al. (1996), clearly showed that the stimulatory effects of increased nutrient loading on epiphyte abundance were greatly reduced when grazers were included in the design of experiments. More recently, a meta-analysis (Hughes et al. 2004) of all of the existing studies, including those cited above, that have compared the relative effects of nutrients and grazers on the epiphytic biomass support our qualitative conclusion that grazers are a key determinant of the extent to which epiphytes can overgrow living seagrass leaves. As they state: 'The positive ef-

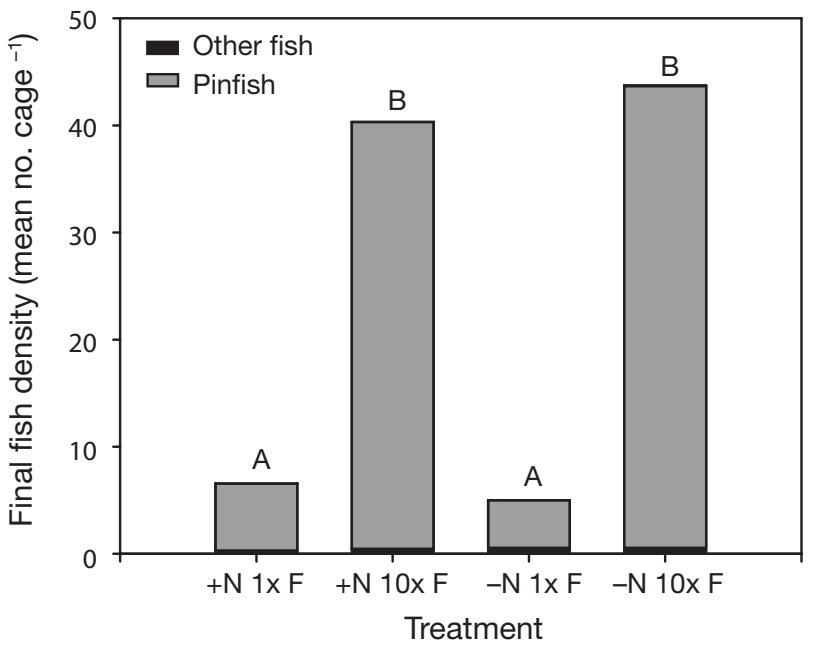

Fig. 13. Mean number of pinfish Lagodon rhomboides and other fish species by treatment seined from cages in October 2000. Treatments with different letters above them are significantly different $(p<0.05)$. Abbreviations as in Fig. 6. Error bars + $1 \mathrm{SE}$

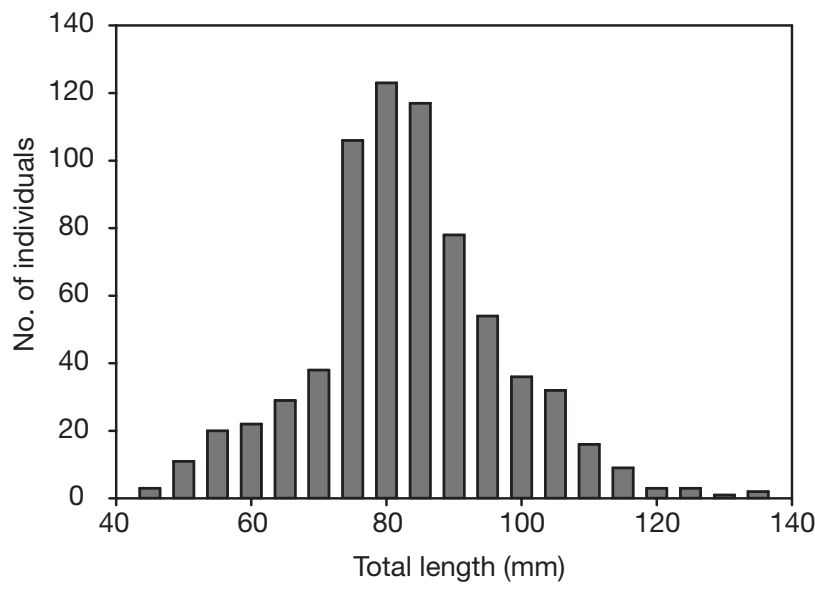

Fig. 14. Lagodon rhomboides. Size frequency distribution of pinfish seined from cages in October 2000

fects of epiphyte grazers were comparable in magnitude to the negative impacts of water column nutrient enrichments, suggesting that the 2 factors should not be considered in isolation of each other.' Thus, mesograzers usually control the abundance of epiphytes, even in enriched conditions, a result inconsistent with the simple paradigm of nutrient-enrichment caused seagrass decline summarized by Duarte (1995) and a number of more recent publications (Howarth et al. 2000, NAS 2000, Hauxwell et al. 2001).

In attempting to interpret our current results, it was important to establish the level of nutrient enrichment and consumer abundances actually achieved in our treatments. We estimate (based on temperature dependent nutrient release rates shown in Fig. 2 of 
Heck et al. 2000) that we delivered between 576 and $886 \mathrm{mmol}$ dissolved inorganic nitrogen (DIN) $\mathrm{m}^{-2} \mathrm{~d}^{-1}$ and 35 and $54 \mathrm{mmol} \mathrm{P} \mathrm{m}^{-2} \mathrm{~d}^{-1}$ to the $+\mathrm{N}$ treatments. These daily rates translate to annual loadings of around 210 to $323 \mathrm{~mol} \mathrm{DIN} \mathrm{m}{ }^{-2} \mathrm{yr}^{-1}$ and 12.8 to 19.7 $\mathrm{mol} \mathrm{PO}_{4} \mathrm{~m}^{-2} \mathrm{yr}^{-1}$ and are much higher than those estimated for most of the major estuaries of the world, as well as those achieved in other seagrass nutrient enrichment studies, including our own (Table 2). While advection of nutrients from our experimental cages undoubtedly occurred, we believe that we were effective in delivering nutrients to our enrichment plots for the following reasons: (1) Big Lagoon is in a low energy environment with limited potential for water flow to remove nutrients from the enclosures (cf. Gorsline 1966); (2) placing the nutrient delivery tubes within the seagrass canopy ensured that nutrient release occurred in an area of very low flow (Koch 2001), and immediately adjacent to algal epiphytes; (3) water column nutrient concentrations were measurably increased; and (4) there was a substantial increase in nitrogen concentrations in Halodule wrightii leaves in $+\mathrm{N}$ treatments (Fig. 11). In addition, we also successfully maintained the pinfish treatments: Fig. 13 shows that densities in the pinfish addition treatment were significantly higher than those in the ambient density treatment, and only a small percentage were smaller than the mesh size of the enclosures. Thus, we did maintain the treatments as intended.

Although we did not observe simple trophic cascades, presumably because pinfish feed at several different trophic levels, the elevated pinfish density treatment did produce a number of consumer effects. For example, reductions in mean crustacean mesograzer densities were observed in the elevated pinfish treatment at the end of the experiment (Fig. 7), even though these differences were not significant. In addition, the high density fish enclosures showed reduced epiphyte chl a (Fig. 8). We believe that two factors account for this. First, omnivorous pinfish consume increasing amounts of plants, including epiphytes, as they grow (Stoner \& Livingston 1984) and were likely to have been consuming substantial amounts of epiphytes during the latter part of the experiment. Second, pinfish also consume seagrass leaves once they grow beyond 100 mm SL (Luczkovich \& Stellwag 1993), and a number of fish in our enclosures were large enough to be consuming shoalgrass at the end of the experiment (Fig. 14). Thus, pinfish could have consumed many of the older and more heavily epiphytized leaves, resulting in an increased relative abundance of young, unepiphytized leaves. And, as we observed, by feeding on leaves they probably also reduced the total number of leaves and biomass of shoalgrass in the $+\mathrm{N}$ enclosures by the end of the experiment (Fig. 9; see below).
With regard to nutrient effects on epiphytes, even though there were significantly more epiphytes (as indicated by chl a concentrations) in the nutrient enrichment treatments at the end of the experiments (due primarily to the $+\mathrm{N} 1 \times \mathrm{F}$ treatment; Fig. 8), the mean epiphyte abundance in the enriched treatments was actually lower at the end than it was at the beginning of the experiments. Thus, even though epiphyte chl a was elevated substantially compared to the start and middle of the experiment in the $+\mathrm{N} 1 \times \mathrm{F}$ treatment, there was a large overall decrease in this treatment from the beginning to the end of the experiment. For this reason, it is difficult to see how epiphyte shading could have been solely responsible for the shoalgrass losses and decreased growth rates in the $+\mathrm{N}$ treatments, since there was no mean accumulation of epiphyte chl a by the end of the experiment, and values were at very low levels during the midpoint (Fig. 8).

As to why the nutrient enrichment enclosures contained lower shoalgrass biomasses than the unenriched enclosures if epiphyte shading is primarily not to blame, we offer two possibilities. One is that the nutrient additions themselves could have produced harmful effects on shoalgrass. This seems unlikely however, as Burkholder et al. (1994) showed that shoalgrass was quite tolerant of very high rates of water column nitrate loading, in contrast to eelgrass, whose growth was negatively affected by nitrate enrichment.

A second explanation, which we favor, is that pinfish and other small grazers such as amphipods fed at high rates on leaves with elevated nitrogen content, just as other fish, turtles, marine mammals, and small crustaceans have been shown to do (Williams 1987, Williams \& Ruckelshaus 1993, McGlathery 1995, Preen 1995, Boyer et al. 2004, Goecker et al. 2005). The prevalence of preferential feeding on nutrient rich foods is well documented (see review by Cebrian 1999), and the discipline of ecological stoichiometry has generated many new and testable hypotheses about the manifold impacts that shifts in nutrient balance can have for consumers (Sterner \& Elser 2002). In this study we loaded nutrients at much higher rates than in our previous experiments (Heck et al. 2000) and thereby increased leaf nitrogen content to very high levels. By doing this it seems that we were unintentionally inducing pinfish and small crustaceans to feed on the enriched seagrass leaves, which resulted in a different outcome than we obtained previously with lower leaf nitrogen concentrations. Thus we believe that the low shoalgrass biomass found in the enriched plots at the conclusion of the experiment resulted from preferential feeding on the nitrogen-rich leaves by the larger pinfish and the small crustaceans and not primarily as an indirect consequence of epiphytic algal overgrowth. 
We conclude by noting that the role of grazers in mediating the effects of eutrophication in seagrass meadows can vary greatly, especially for organisms like the pinfish, which switch from carnivory to herbivory during ontogeny. The complexities in the relationships among nutrients, algal and seagrass food quality, and grazers that we have observed indicate that there is still much to learn about the interacting effects of nutrient supplies and consumer effects in seagrass meadows. In particular, the occasions when enriching food items makes them more palatable to consumers injects additional complexity into understanding and predicting the effects of eutrophication in coastal waters.

Acknowledgements. We thank K. Kirsch, L. Gallagher, T. Berrell, D. Byron, and M. Ferdie along with a host of other graduate students, for help in field sampling and cage maintenance, and C. Wood for manuscript preparation. Support was provided by the Environmental Protection Agency, the Alabama Center for Estuarine Studies (ACES), the Dauphin Island Sea Lab, and the University of South Alabama. This is DISL Publication Number 383.

\section{LITERATURE CITED}

Boyer KE, Fong P, Armitage AR, Cohen RA (2004) Elevated nutrient content of tropical macroalgae increases rates of herbivory in coral, seagrass and mangrove habitats. Coral Reefs 23:530-538

Burkholder JM, Glasgow HB Jr, Cooke JE (1994) Comparative effects of water-column nitrate enrichment on eelgrass Zostera marina, shoalgrass Halodule wrightii, and widgeongrass Ruppia maritima. Mar Ecol Prog Ser 105: 121-138

Cambridge ML, McComb AJ (1984) The loss of seagrasses in Cockburn Sound, Western Australia. I. The time course and magnitude of seagrass decline in relation to industrial development. Aquat Bot 20:229-243

Cebrian J (1999) Patterns in the fate of production in plant communities. Am Nat 154:449-468

Duarte CM (1995) Submerged aquatic vegetation in relation to different nutrient regimes. Ophelia 41:37-112

Duffy JE, Richardson JP, Canuel EA (2003) Grazer diversity effects on ecosystem functioning in seagrass beds. Ecol Lett 6:637-645

Gacia E, Littler MM, Littler DS (1999) An experimental test of the capacity of food web interactions (fish-epiphytes-seagrasses) to offset the negative consequences of eutrophication on seagrass communities. Estuar Coast Shelf Sci 48: 757-766

Giesen WBJT, van Katwijk MM, den Hartog C (1990) Eelgrass condition and turbidity in the Dutch Wadden Sea. Aquat Bot 37:71-85

Goecker ME, Heck KL Jr, Valentine JF (2005) Effects of nitrogen concentrations in turtlegrass Thalassia testudinum on consumption by the bucktooth parrotfish Sparisoma radians. Mar Ecol Prog Ser 286:239-248

Gorsline DS (1966) Dynamic characteristics of west Florida Gulf coast beaches. Mar Geol 4:187-206

Harlin MM, Thorne-Miller B (1982) Seagrass-sediment dynamics of a flood-tidal delta in Rhode Island. Aquat Bot 14:127-138

Hauxwell J, Cebrian J, Furlong C, Valiela I (2001) Macroalgal canopies contribute to eelgrass (Zostera marina) decline in temperate estuarine ecosystems. Ecology 82:1007-1022

Heck KL Jr, Pennock JR, Valentine JF, Coen LD, Sklenar SA (2000) Effects of nutrient enrichment and small predator density on seagrass ecosystems: an experimental assessment. Limnol Oceanog 45:1041-1057

Heck KL Jr, Hays CG, Orth RJ (2003) Critical evaluation of the nursery hypothesis for seagrass meadows. Mar Ecol Prog Ser 253:123-136

Howarth R, Anderson D, Cloern J, Elfring C and 7 others (2000) Nutrient pollution of coastal rivers, bays and seas. Issues Ecol 7:1-15

Hughes AR, Bando KJ, Rodriguez LF, Williams SL (2004) Relative effects of grazers and nutrients on seagrasses: a meta-analysis approach. Mar Ecol Prog Ser 282:87-99

Huh SH (1984) Seasonal variations in populations of small fishes concentrated in shoalgrass and turtlegrass meadows. J Oceanol Soc Korea 19:44-55

Jernakoff P, Brearley A, Nielsen J (1996) Factors affecting grazer-epiphyte interactions in temperate seagrass meadows. Oceanog Mar Biol Annu Rev 34:109-162

Kjelson MA, Johnson GN (1978) Catch efficiencies of a 6.1 meter otter trawl for estuarine fish populations. Trans Am Fish Soc 107:246-254

Koch EW (2001) Beyond light: physical, geological, and geochemical parameters as possible submersed aquatic vegetation habitat requirements. Estuaries 24:1-17

Larkum AWD, Koop K (1997) Encore, algal productivity and possible paradigm shifts. Proc 8th Intl Coral Reef Symp $1: 881-884$

Lotze HK, Worm B (2002) Complex interactions of climatic and ecological controls on macroalgal recruitment. Limnol Oceanogr 47:1734-1741

Luczkovich JJ, Stellwag EJ (1993) Isolation of cellulolytic microbes from the intestinal tract of the pinfish, Lagodon rhomboides: size-related changes in diet and microbial abundance. Mar Biol 116:381-388

McGlathery KJ (1995) Nutrient and grazing influences on a subtropical seagrass community. Mar Ecol Prog Ser 122: 239-252

Miller MW, Hay ME, Miller SL, Malone D, Sotka EE, Szmant AM (1999) Effects of nutrients versus herbivores on reef algae: a new method for manipulating nutrients on coral reefs. Limnol Oceanogr 44:1847-1861

NAS (National Academy of Sciences) (2000) Clean coastal waters: understanding and reducing the effects of nutrient pollution. National Academy Press, Washington, DC

NSF (National Science Foundation) (2000) Ocean sciences at the new millennium. Proc Univ Corp Atmos Res Joint Office Sci Sup

Neckles HA, Wetzel RL, Orth RJ (1993) Relative effects of nutrient enrichment and grazing on epiphyte macrophyte (Zostera marina) dynamics. Oecologia 93:285-295

Nixon SW, Oviatt C, Frithsen J, Sullivan B (1986) Nutrients and productivity of estuaries and coastal marine ecosystems. J Limnol Soc S Afr 12:43-71

Nixon S, Buckley B, Granger S, Bintz J (2001) Responses of very shallow marine ecosystems to nutrient enrichment. Human Ecol Risk Assess 7:1457-1481

Orth RJ, Van Montfrans J (1987) Utilization of seagrass meadow and tidal marsh creek by blue crabs Callinectes sapidus. I. Seasonal and annual variations in abundance with emphasis on post-settlement juveniles. Mar Ecol Prog Ser 41:283-294 
Preen A (1995) Impacts of dugong foraging on seagrass habitats: observational and experimental evidence for cultivation grazing. Mar Ecol Prog Ser 124:201-213

Short FT, Burdick DM, Kaldy JE III (1995) Mesocosm experiments quantify the effects of eutrophication on eelgrass, Zostera marina. Limnol Oceanogr 40:740-749

Solorzano L, Sharp JH (1980) Determination of total dissolved phosphorus and particulate phosphorus in natural waters. Limnol Oceanogr 25:754-758

Spitzer PM, Mattila J, Heck KL Jr (2000) The effects of vegetation density on the relative growth rates of juvenile pinfish, Lagodon rhomboides (Linneaus), in Big Lagoon, Florida. J Exp Mar Biol Ecol 244:67-86

Steneck RS, Carlton JT (2001) Human alterations of marine communities - students beware! In: Bertness MD, Gaines SD, Hay ME (eds) Marine community ecology. Sinauer Associates, Sunderland, MA, p 445-468

Sterner RW, Elser JJ (2002) Ecological stoichiometry. Princeton University Press, Princeton, NJ

Editorial responsibility: Otto Kinne (Editor-in-Chief), Oldendorf/Luhe, Germany
Stoner AW, Livingston RJ (1984) Ontogenetic patterns in diet and feeding morphology in sympatric sparid fishes from seagrass meadows. Copeia 41:174-187

Strickland JDH, Parsons TR (1972) A practical handbook for seawater analysis. Fish Res Boaard Can Bull 167

Thompson K (2000) Feeding ecology and production of the pinfish Lagodon rhomboides in temperate seagrass meadows. PhD dissertation, University of South Alabama, Mobile, AL

Valentine JF, Heck KL Jr (1991) The role of sea urchin grazing in regulating subtropical seagrass meadows: evidence from field manipulations in the northern Gulf of Mexico. J Exp Mar Biol Ecol 154:215-230

Williams SL (1987) Competition between the seagrasses Thalassia testudinum and Syringodium filiforme in a Caribbean lagoon. Mar Ecol Prog Ser 35:91-98

Williams SL, Ruckelshaus MH (1993) Effects of nitrogen availability and herbivory on eelgrass (Zostera marina) and epiphytes. Ecol 74:904-918

Submitted: August 19, 2005; Accepted: April 21, 2006

Proofs received from author(s): October 25, 2006 